\title{
ЭКОЛОГИЯ
}

\section{И ПРИРОДОПОЛЬЗОВАНИЕ}

DOI: https://doi.org/10.15688/jvolsu11.2017.3.4

UDC 631.461(470+571)

LBC 40.325.1(2Poc)

\section{FEATURES OF MICROBIAL COMMUNITIES IN ZONAL SOILS OF THE ARID ZONE SOUTH-EAST OF THE EUROPEAN PART OF RUSSIA ${ }^{1}$}

\author{
Nadejda Valerievna German \\ Volgograd State University, Volgograd, Russian Federation \\ Elena Anatolyevna Ivantsova \\ Volgograd State University, Volgograd, Russian Federation \\ Anna Viktorovna Kholodenko \\ Volgograd State University, Volgograd, Russian Federation
}

\begin{abstract}
Ensuring sustainable functioning of agricultural systems in arid conditions remains an urgent problem of rational nature management for the South-East of the European part of Russia. This is confirmed by the agricultural specialization of the RF subjects located in this region, including the Volgograd region. The lower Volga region is the most" fragile "territory of the European part of the arid zone of Russia. The article deals with the peculiarities of formation of soil microbial communities taking into account the specifics of natural and climatic conditions of the arid zone. The importance of research data on the characteristics of the microbial community of the soil in the regulation of the functioning of agrocenoses arid zone.

Conditionally prevailing in a zone of distribution of zonal soils of arid zone of the Southeast of the European part of Russia microorganisms can be attributed on their specific accessory to three of the main functional groups (ecological niches). The selected groups have a certain list of species that implement

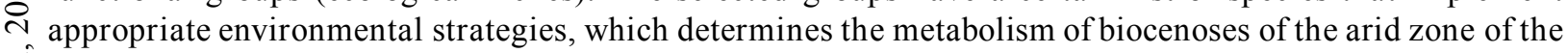
ต่ Lower Volga region.

A detailed research of these groups of microorganisms will unify the definition of the dynamics of communities and predict changes in the structure and activity of the whole biocenosis. Including changes related to directional effects in the target groups of microorganisms. Also relevant is the study of elements of biocenoses in the complex of relationships between key participants (soil microbiota, flora, entomofauna). It is equally important to take into account the relationship with groups of factors that form and influence the interaction within biocenoses, including arid conditions on the border of conditionally natural steppe biocenoses and agrocenoses.
\end{abstract}

Key words: the microbial community, zonal soils, aridity, risk of agriculture, biocenosis, a agrocenosis. 
УДК 631.461(470+571)

ББК 40.325.1(2Poc)

\title{
ОСОБЕННОСТИ МИКРОБНЫХ СООБЩЕСТВ В ЗОНАЛЬНЫХ ПОЧВАХ АРИДНОЙ ЗОНЫ ЮГО-ВОСТОКА ЕВРОПЕЙСКОЙ ЧАСТИ РОССИИ ${ }^{1}$
}

\author{
Надежда Валерьевна Герман \\ Волгоградский государственный университет, г. Волгоград, Российская Федерация \\ Елена Анатольевна Иванцова \\ Волгоградский государственный университет, г. Волгоград, Российская Федерация \\ Анна Викторовна Холоденко \\ Волгоградский государственный университет, г. Волгоград, Российская Федерация
}

\begin{abstract}
Аннотация. Для Юга России актуальной проблемой рационального природопользования остается обеспечение устойчивого функционирования агросистем в аридных условиях, что подтверждается сельскохозяйственной специализацией Волгоградской области и прилегающих субъектов РФ. Нижнее Поволжье является наиболее «хрупкой» территорией европейской части аридного пояса России. В статье рассмотрены особенности формирования почвенных микробных сообществ с учетом специфики природно-климатических условий аридной зоны. Выделены основные экологические ниши, занимаемые почвенными микроорганизмами в зональных почвах сухих степей и полупустынь. Также рассмотрено значение исследовательских данных о характеристиках микробного сообщества почвы при регулировании показателей функционирования агроценозов аридной зоны.
\end{abstract}

Ключевые слова: микробные сообщества, зональные почвы, аридность, рисковое земледелия, биоценоз, агроценоз.

Зависимость материально-энергетической динамики биоценоза от влияния почвенных и климатических условий, а также особенности влияния аридности на состояние естественных и искусственных экосистем рассмотрены российскими и зарубежными исследователями. Аридность воспринимается элементами биоценоза как стрессовый фактор и вызывает специфические реакции [20, 24-26].

Основным районом исследования была выбрана Волгоградская область с учетом зональных почвенно-климатических условий, которые соотносятся с северной границей аридной зоны на юго-востоке Европейской части России.

Волгоградская область в точки зрения природного районирования относится к юговостоку Европейской части России и в зональном распределении природных комплексов соотносится со степной зоной, природно-экологические особенности которой закономерно изменяются по оси с северо-запада на юговосток. Такая зональная смена определяется нарастанием степени континентальности климата, что отражается в закономерной смене значений гидротермического коэффициента, сменой преобладающего типа почв и почвенных процессов (от черноземов обыкновенных и южных, каштановых почв до бурых полупустынных, нарастание комплексности почвенного покрова в связи с процессами осолонцевания), растительного покрова.

По общепринятой классификации территория области относится к континентальной Восточно-европейской климатической провинции. Характерными особенностями климата региона являются небольшое количество осадков, часто повторяющиеся засухи. Отличительной и наиболее неблагоприятной для сельскохозяйственного производства особенностью климата является резкий дефицит влаги поздней весной и в начале лета. Агроклиматические условия ухудшаются активным ветровым режимом, частыми суховеями, что усиливает испарение и резко снижает запасы продуктивной влаги в почве Территория Нижнего Поволжья располагает значительными радиационными и тепловыми $\left(\Sigma\right.$ te $\geq 5{ }^{\circ} \mathrm{C}=2900-4000 ; \Sigma$ te $\geq 10{ }^{\circ} \mathrm{C}=2700$ $3600)$ ресурсами, продолжительным периодом 
активной вегетации (155-183 дня), но имеет низкую влагообеспеченность (Р = 243-400 мм), при испаряемости 800-1200 мм . В лесостепной зоне с недостаточным увлажнением величина гидротермического коэффициента равна 1,1-1,3, в степной засушливой зоне он уменьшается до 0,71,0 , а в сухой степи с очень засушливыми погодными условиями - до 0,4-0,7. При этом в условиях юго-востока $54 \%$ от суммы годовых осадков теряется на физическое испарение; если учесть это, то получается, что на создание урожая расходуется лишь 35-40 \% всех осадков. Область относится к районам с повышенными скоростями ветра, что обусловлено преобладанием открытых безлесных степных пространств. Именно в периоды развития сильных ветров температура воздуха достигает максимума, а относительная влажность - минимума $[16,17]$.

Комплекс указанных факторов делает большую часть территории Волгоградской области зоной рискованного земледелия.

Отличительной чертой ландшафтов является разреженность, пятнистость растительного покрова. Вторая особенность - комплексность, обусловленная мельчайшими неровностями рельефа, а также различной увлажненностью и засоленностью [9, 15-17].

Связь между микробиотой и продуктивностью растительных сообществ, особенно применительно к агроценозам, является актуальным объектом изучения с точки зрения повышения эффективности управления сельскохозяйственным природопользованием.

Продуктивность как важнейшая характеристика естественных и агроценозов, для последних складывается под влиянием ряда факторов, включая плодородие почвы, биологические особенности микробного сообщества, гидрометеорологические условия и применяемую технологию возделывания в растениеводстве. Масса почвенной микробиоты составляет большую часть общей массы всех микроорганизмов в наземных экосистемах. При том, что в почве обитают десятки тысяч видов бактерий, лишь небольшая доля этих микроорганизмов ( 20 \%) выделена и охарактеризована $[10,23,27]$. Таким образом, ключевым направлением исследований можно считать изучение базовых закономерностей формирования микробиоценозов зональных почв.
Подзона сухих степей вообще характеризуется аридными условиями, и влажность является одним из основных факторов, ограничивающих развитие микроорганизмов в каштановых почвах. Почти постоянный дефицит влаги в каштановых почвах обуславливает развитие спорообразующих бактерий и актиномицетов, которые легче переносят неблагоприятные условия окружающей среды и являются агентами. В моменты благоприятного сочетания температуры и влажности в каштановых почвах отмечается высокая напряженность микробиологических процессов $[13,22]$.

На инициальной стадии почвообразования происходит заселение почвообразующего субстрата микробным ценозом, состоящим в основном из микобактерий, проактиномицетов и актиномицетов. На основании исследования широкого спектра примитивных почв, такую микобактериально-проактиномицетноактиномицетную стадию проходит каждая примитивная почва, независимо от широтного положения [18]. Далее происходит заселение почвообразующих субстратов олиготрофной микрофлорой, представленной истинными споровыми и неспоровыми бактериями. Растения в это время еще отсутствуют [14].

Вторая стадия развития почв связана с поселением на их поверхности растений и формированием простой растительной группировки. Процесс формирования этой группировки идет достаточно быстро в степной зоне.

Третья стадия развития почв связана с формированием сложной растительной группировки [14].

При исследовании микробных сообществ песков на различных стадиях зарастания в степной зоне наблюдалось постепенное формирование фитоценозов и устойчивого микробного сообщества. Происходило постепенное усложнение трофических функций микробных сообществ и усиление их минерализационной активности $[3,12]$.

Большую роль в деструкции органического вещества почвы играют такие группы гидролитических бактерий, как целлюлолитики и протеолитики. Они обнаруживаются во всех генетических горизонтах почв и занимают значительное место в микробном сообществе. Актиномицеты широко распрост- 


\section{ЭКОЛОГИЯ И ПРИРОДОПОЛЬЗОВАНИЕ}

ранены в почвах аридных районов, так как они по сравнению с другими бактериями более устойчивы к высушиванию. Наличие экзоспор позволяет им сохранять жизнеспособность даже в условиях полного высушивания. В некоторых почвенных образцах в карбонатном горизонте наблюдается даже увеличение их численности. Как отмечают некоторые авторы, карбонатные породы являются одним из характерных местообитанийактиномицетов [11]. Протеазной активностью обладают практически все культуры, за исключением нескольких культур бактерий-сапрофитов, и характеризуются широкой их вариабельностью.

Микробные сообщества играют важную санитарную роль в почве, разлагая пестициды и другие поллютанты. Исследованиями установлено, что трансформация пестицидов в почвах различных ценозов (пастбище, пашня, лес (дуб)) происходила только за счет деятельности микроорганизмов. В стерильных почвах разложение пестицидов не отмечено $[1,4]$.

Исследованиями многих авторов $[1,2,4$ 7] установлено, что в почвах пашни происходит резкое уменьшение биомассы грибов и бактериального населения почв в целом по сравнению с целинным аналогом.

Интенсивность гумусообразования тесно связана с жизнедеятельностью этих микроорганизмов и максимальна в лесных почвах. Уменьшение количества и биомассы грибов в пахотных почвах, обусловленное изменением условий почвенной среды, является одной из важнейших причин уменьшения содержания гумуса и утраты почвой структуры, так как основное цементирующее звено - гуминовые кислоты - образуются при значительном участии грибов.

Изменение численности основных групп почвенных микроорганизмов происходит при различных способах обработки почвы и системах удобрений в севообороте. Среди биологических индикаторов, характеризующих различные аспекты состояния почвенной биоты, ведущее место занимают почвенные микроорганизмы вследствие своей высокой лабильности, исключительно четкой способности реагировать на изменения, происходящие в почве.

В настоящее время механизмы функционирования микробных сообществ в почвах вы- яснены еще не достаточно и требуют детализации количественно-качественных характеристик биогенности почв. Известно, что именно они обеспечивают стабильную устойчивость и продуктивность биогеоценозов [7, 19, 21].

В итоге сформировалось единое представление об экологических нишах почвенной микробиоты, которое разбивает всю ее совокупность на 4 условных группы микроорганизмов: зимогенная, олиготрофная, автохтонная и автотрофная микрофлора $[2,5$, $8,10,11,23]$.

Первые три группы микроорганизмов относятся к гетеротрофам (органотрофам), которые в своем питании нуждаются в готовом органическом веществе. В свою очередь, автотрофная микрофлора способна образовывать органическое вещество в собственных клетках и для этого использует в питании вещества неорганической природы. Поэтому многие из автотрофных микроорганизмов почвы являются литотрофами.

Зимогенная микрофлора в обычном состоянии почвы (неудобренность или промежуток времени между поступлениями растительных остатков в почву) небольшая по количеству группа микроорганизмов, которая, как правило, дает резкий подъем своей численности в момент поступления свежего органического вещества, так как специализируется на разложении легкодоступных органических соединений растительного и животного происхождения. Из бактерий в эту группу входят представители р. Bacillus, Pseudomonas, Arthrobacter, из грибов - p. Aspergillus, Penicillium, Fusarium, Cladosporium, в том числе дрожжевые формы р. Lypomyces, Cryptococcus, Candida и многие другие виды микроорганизмов.

Олиготрофная микрофлора составляет большую часть почвенного микронаселения, представители которого усваивают питательные вещества из растворов с низкой концентрацией как азотсодержащих (олигонитрофилы), так и безазотистых углеродсодержащих органических (олигокарбофилы) соединений. Названная «микрофлорой рассеяния», эта группа, по сути, является преемницей минерализационного процесса, активируемого зимогенной микрофлорой, и завершает разложение остатков свежего органического вещества. Сюда входят многие бак- 
терии р. Hyphomicrobium, Ancalomicrobium, Prosthemicrobium, Stella, Seliberia, Caulobacter, Renobacter и другие роды и виды.

Зимогенная и олиготрофная часть микробоценоза почвы объединяется вобщую группу сапротрофных микроорганизмов(или сапротрофов), поскольку перерабатывают мертвое органическое вещество остатков растений и животных различной степени разложенности.

Таким образом, условно преобладающие в зоне распространения зональных почв аридной зоны юго-востока европейской части России микроорганизмы можно в зависимости от их видовой принадлежности отнести к трем из основных функциональных групп (экологических ниш) (рис. 1). Выделенные группы имеют определенный перечень видов, реализующих соответствующие экологические стратегии, что определяет особенности метаболизма биоценозов аридной зоны Нижнего Поволжья.

Детальное изучение указанных групп микроорганизмов позволит унифицировать оп- ределение особенностей динамики сообществ и прогнозировать изменения в структуре и жизнедеятельности всего биоценоза, включая целенаправленные воздействия на целевые группы микроорганизмов. Также актуальным остается изучение элементов биоценозов в едином комплексе взаимосвязей между ключевыми участниками (почвенная микробиота, флора, энтомофауна) и во взаимосвязи с группами факторов, формирующих и влияющих на эти взаимодействия, в том числе в аридных условиях на границе квазиестественных степных биоценозов и агроценозов.

\section{ПРИМЕЧАНИЕ}

${ }^{1}$ Публикация подготовлена при финансовой поддержке Государственного задания Минобрнауки РФ по теме «Разработка экологоориентированных биотехнологий опти-мизации аридных агробиоценозов Юга России на основе достижений физико-химической биологии и биоинформатики» (проект № 40.7534.2017/8.9).

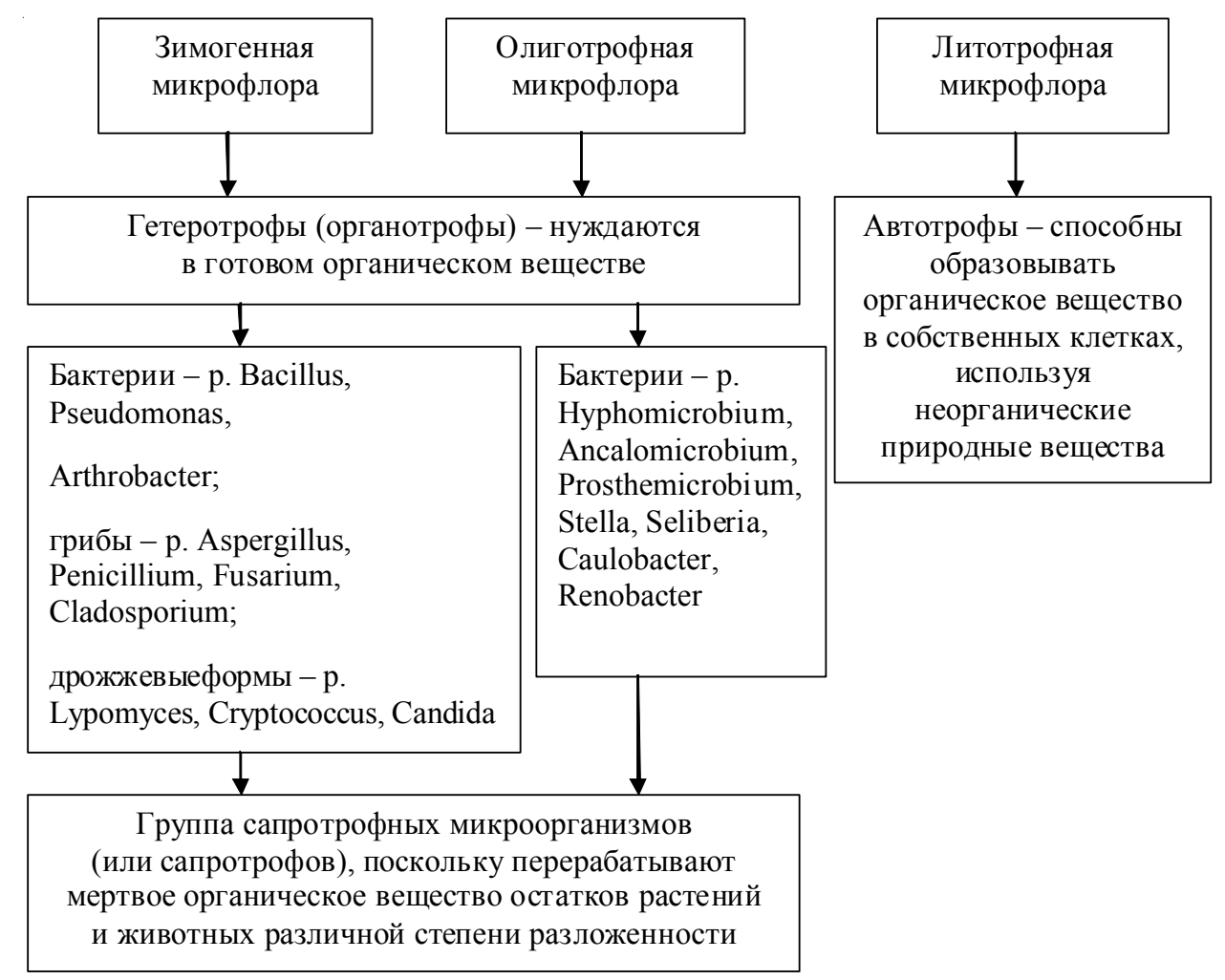

Рис. 1. Экологические ниши почвенной микробиоты

Примечание. Составлено по данным $[2,5,8,10,11,23]$. 


\section{СПИСОК ЛИТЕРАТУРЫ}

1. Ананьева, Н.Д. Микробиологическая оценка почв в связи с самоочищением от пестицидов и устойчивостью к антропогенным воздействиям : автореферат дис. ... доктора биологических наук : 03.00.27, 03.00.07 / Ананьева Надежда Дмитриевна / Моск. гос. ун-т им. М. В. Ломоносова. Москва, 2001. - 49 с.

2. Ананьева, Н. Д. Оценка устойчивости микробных комплексов почв к природным и антропогенным воздействиям / Н. Д. Ананьева, Е. В. Благодатская, Т. С. Демкина // Почвоведение. - 2002. - № 5. - С. 580-587.

3. Андреюк, Е. И. Микробные сообщества песков на различных стадиях естественного зарастания / Е. И. Андреюк, Е. В. Валагурова, Е. А. Мятликова, Е. С. Гуменко, Г. А. Ткачева // Микробиологический журнал. - 1989. - Т. 51. - № 2. - С. 8-12.

4. Балаян, Т. В. Биологическая активность дерново-подзолистой почвы и урожай сельскохозяйственных культур / Т. В. Балаян // Почвоведение. - 1993. - № 12. - С. 65-71.

5. Белоголова, Г.А. Влияние почвенных бактерий на поведение химических элементов в системе почва-растение / Г.А. Белоголова, М. Г. Соколова, О.А. Пройдакова // Агрохимия. - 2011. - № 9. C. $68-76$.

6. Берестецкий, О.А. Влияние растительных остатков на почвенно-микробиологические процессы в полях севооборота / О.А. Берестецкий, Ю.М. Возняковская, Ж.П. Попова // Труды Всесоз. науч.- исслед. ин-та сел. хоз. микробиологии. 1983. - Т. 53. - С. 5-15.

7. Валько, В. П. Особенности биотехнологического земледелия / В. П. Валько, А. В. Щур. Минск : БГАТУ, 2011. - $196 \mathrm{c}$.

8. Васильева, Л. В. Олиготрофы как компонент биогеоценоза / Л. В. Васильева // Почвенные организмы как компоненты биогеоценоза. - М. : Наука, 1984. - С. 232-241.

9. Дегтярева, Е. П. Почвы Волгоградской области / Е. П. Дегтярева, А. Н. Жулидова. - Волгоград: Ниж.-Волж. кн. изд-во, 1970. - 320 с.

10. Добровольская, Т. Г. Почвы и микробное разнообразие / Т. Г. Добровольская, Л. В. Лысак, Д. Г. Звягинцев // Почвоведение. - 1996. - № 6. С. 699-704.

11. Добровольский, Г. В. Роль почвы в формировании и сохранениибиологического биоразнообразия / Г. В. Добровольский, И. Ю. Чернов. М. : Товарищество научных изданий КМК, 2011.$273 \mathrm{c}$.

12. Иутинская, Г. А. Микробные ценозы и органическое вещество освоенных песчаных почв нижнего Днепра / Г. А. Иутинская, С. П. Голобо- родько, Н. В. Иличко, Н. Ф. Кигель, Н. И. Иванова // Микробиологический журнал. - 1986. - № 6. C. 3-8.

13. Клевенская, И. Л. Микрофлора почв Западной Сибири / И. Л. Клевенская, Н. Н. Наплекова, Н. И. Гантимурова. - Новосибирск : Наука, Сиб. отд-ние, 1970. -222 с.

14. Клевенская, И. Л. Склоновые процессы техногенных экосистем как фактор почвообразования / И. Л. Клевенская, С. А. Таранов, С. С. Трофимов, Ф. А. Фаткулин // Техногенные экосистемы. Организация и функционирование. - Новосибирск : Наука, Сиб. отд-ние, 1985. - С. 23-38.

15. Околелова, А.А. Принципы формирования фонда почвенно-генетического разнообразия Волгоградской области [Текст] : автореф. дис. ... д-ра биол. наук: 03.00.27 / Околелова Алла Ароновна. - Ростов-на-Дону, 2005. - 52 с.

16. Природные условия и ресурсы Волгоградской области /под ред. проф. В.А. Брылева. Волгоград : Перемена, 1995. - 264 с.: ил.

17. Сажин, А. Н. Погода и климат Волгоградской области / А. Н. Сажин, К. Н. Кулик, Ю. И. Васильев. - Волгоград: ВНИАЛМИ, 2010. - 306 с.

18. Титлянова, А. А. Сукцессии и биологический круговорот / А. А. Титлянова, Н. А. Афанасьев, Н. Б. Наумова [и др.]; отв. ред. В. М. Курачев. Новосибирск: Наука, Сиб. отд-ние, 1993. - 157 с.

19. Туманян, А.Ф. Способ обработки почвы и продуктивность зерновых культур в аридной зоне / А. Ф. Туманян, Н. В. Тютюма // Земледелие-2012. №. 4. - C. 25-26.

20. Шабаев, А.И. Адаптивно-экологический вектор развития ландшафтного земледелия на юговостоке европейской части России / А.И. Шабаев // Аграрный вестник Юго-Востока. - 2009. - № 1 (1). C. 41-44.

21. Щур, А. В. Влияние способов обработки почвы и внесения удобрений на численность и состав микроорганизмов / А. В. Щур, В. П. Валько, Д. В. Виноградов // Вестник Курской государственной сельскохозяйственной академии. - 2015. № 3. - С. 41-44.

22. Якутин, М.В. О системе показателей мониторинга экосистем сухих степей / М. В. Якутин, Д. С. Дубовик // Вестник Сибирской государственной геодезической академии. - 2012. - № 18-2. C. 94-99.

23. Delmont, T.O. Accessing the soil metagenome for studies of microbial diversity / T. O. Delmont, P. Robe, S. Cecillon, I. M. Clark, P. F. Constancias, Simonet, P.R. Hirsch, T.M. Vogel // Applied and Environmental Microbiology. - 2011. - Vol. 77. - № 4. - P. 1315-1324.

24. Drenovsky, R. E. A functional trait perspective on plant invasion / R. E. Drenovsky, B. J. Grewell, C. M. D’Antonio, J. L. Funk, J. J. James, 
N. Molinari, et al // Ann. Bot. - 2012. - № 110 (1). p. $141-153$.

25. El-Sayed, W. S. In vitro antagonistic activity,plant growth promoting traits and phylogenetic affiliation of rhizobacteria associated with wild plants grown in arid soil/ W. S. El-Sayed, A. Akhkha, M. Y. ElNaggar, M. Elbadry // Front. Microbiol. - 2014. № 5 - p. 651 .

26. He, M. Leaf nitrogen and phosphorus of temperate desertplants in response to climate and soil nutrient availability / M. He, F.A. Dijkstra, K. Zhang, X. Li, H. Tan, Y. Gao, G. Li // Sci. Rep. - 2014. - № 4. p. 6932.

27. Saha, P. Phylogenetic analysis of tolerant bacteria from Partheniumhysterophorus (1.) amended soil by bootstrap approach/P. Saha, S. Kumari, B. S. Raipat, M. P. Sinha // International Journal of Microbiological Research. -2011. - №2 (2). - P. 176-183.

\section{REFERENCES}

1. Anan'eva, N.D. Mikrobiologicheskaja ocenka pochv $\mathrm{v}$ svjazi s samoochishheniem ot pesticidov i ustojchivost'ju $\mathrm{k}$ antropogennym vozdejstvijam [Microbiological evaluation of soils in connection with the purification from pesticides and resistance to anthropogenic influences]: avtoreferat dis.... doktora biologicheskih nauk : 03.00.27, 03.00.07 / Anan'eva Nadezhda Dmitrievna / Mosk. gos. un-t im. M. V. Lomonosova. - Moskva, 2001. -49 s.

2. Anan'eva N.D., Blagodatskaja E.V., Demkina T.S. Ocenka ustojchivosti mikrobnyh kompleksov pochv $\mathrm{k}$ prirodnym i antropogennym vozdejstvijam [Assessment of the sustainability of microbial complexes in soils of natural and anthropogenic influences], Pochvovedenie [Pedology] , 2002, no. 5, pp. 580-587.

3. Andrejuk E.I., Valagurova E.V., Mjatlikova E.A., Gumenko E.S., Tkacheva G.A. Mikrobnye soobshhestva peskov na razlichnyh stadijah estestvennogo zarastanija [The microbial community of the Sands at various stages of natural revegetation, Mikrobiologicheskij zhurnal [Microbiological journal], 1989, T. 51, no. 2. - s. 8-12.

4. Balajan, T.V. Biologicheskaja aktivnost' dernovo-podzolistoj pochvy i urozhaj sel'skohozjajstvennyh kul'tur [Biological activity of sod-podzolic soil and the yield of crops], Pochvovedenie [Pedology], 1993, no. 12, pp. 65-71.

5. Belogolova G.A., Sokolova M.G., Projdakova O.A. Vlijanie pochvennyh bakterij na povedenie himicheskih jelementov $\mathrm{v}$ sisteme pochvarastenie [Influence of soil bacteria on the behavior of chemical elements in the soil-plant system], Agrohimija [Agrochemistry], 2011, no. 9, pp. 68-76.
6. Beresteckij O.A., Voznjakovskaja Ju.M., Popova Zh.P. Vlijanie rastitel'nyh ostatkov na pochvenno-mikrobiologicheskie processy $\mathrm{v}$ poljah sevooborota [Influence of plant residues on soil and microbiological processes in crop rotation fields], Trudy Vsesoz. nauch.- issled. in-ta sel. hoz. Mikrobiologii, 1983, T.53, pp.5-15.

7. Val'ko V.P., Shhur A.V. Osobennosti biotehnologicheskogo zemledelija. Minsk, BGATU, 2011, 196 p.

8. Vasil'eva L.V. Oligotrofy kak komponent biogeocenoza [The oligotrophs as a component of biogeocenosis], Pochvennye organizmy kak komponenty biogeocenoza[Soil organisms as components of ecosystems]. Moscow, Nauka, 1984, pp. 232-241.

9. Degtjareva E.P., Zhulidova A.N. Pochvy Volgogradskoj oblasti. Volgograd, Nizh.-Volzh. kn. izdvo, 1970, 320p.

10. Dobrovol'skaja T.G., Lysak L.V., Zvjagincev D.G. Pochvy i mikrobnoe raznoobrazie [Soils and microbial diversity], Pochvovedenie [Pedology],1996, no. 6, pp. 699-704.

11. Dobrovol'skij G.V., Chernov I.Ju. Rol' pochvy v formirovanii i sohranenii biologicheskogo raznoobrazija. Moscow, Tovarishhestvo nauchnyh izdanij KMK, 2011, 273 p.

12. Iutinskaja G.A., Goloborod'ko S.P., Ilichko N.V., Kigel' N.F., Ivanova N.I.Mikrobnye cenozy i organicheskoe veshhestvo osvoennyh peschanyh pochv nizhnego Dnepra [Microbial cenosis and organic matter of the mastered sandy soils of the lower Dnieper], Mikrobiologicheskij zhurnal [Microbiological journal], 1986, no. 6, pp. 3-8.

13. Klevenskaja I.L., Naplekova N.N., Gantimurova N.I. Mikroflora pochv Zapadnoj Sibiri. Novosibirsk, Nauka, Sib. otd-nie, 1970, 222 p.

14. Klevenskaja I.L., Taranov S.A., Trofimov S.S., Fatkulin F.A. Sklonovye processy tehnogennyh jekosistem kak faktor pochvoobrazovanija, Tehnogennye jekosistemy. Organizacija i funkcionirovanie. Novosibirsk, Nauka, Sib. otd-nie, 1985, pp. 23-38.

15. Okolelova A.A. Principy formirovanija fonda pochvenno-geneticheskogo raznoobrazija Volgogradskoj oblasti: avtoref. dis. ... d-rabiol. nauk: 03.00.27/ Okolelova Alla Aronovna. Rostov-na-Donu, 2005, 52p.

16. Prirodnye uslovija i resursy Volgogradskoj oblasti /pod red. prof. V.A. Bryleva. Volgograd, Peremena, 1995, $264 \mathrm{p}$.

17. Sazhin A.N., Kulik K.N., Vasil'ev Ju.I.Pogoda i klimat Volgogradskoj oblasti. Volgograd, VNIALMI, $2010,306 \mathrm{p}$.

18. Titljanova A.A., Afanas'ev N.A., Naumova N.B. Sukcessii i biologicheskij krugovorot. Novosibirsk, Nauka, Sib. otd-nie, 1993, 157 s. 


\section{ЭКОЛОГИЯ И ПРИРОДОПОЛЬЗОВАНИЕ}

19. Tumanjan A.F., Tjutjuma N.V. Sposob obrabotki pochvy i produktivnost' zernovyh kul'tur v aridnoj zone [A method of processing soil and productivity of crops in the arid zone], Zemledelie [Agriculture], 2012, no. 4, pp. 25-26.

20. Shabaev A.I. Adaptivno-jekologicheskij vektor razvitija landshaftnogo zemledelija na jugovostoke evropejskoj chasti Rossii [Adaptiveecological vector of development of landscape agriculture in the Southeast of the European part of Russia], Agrarnyj vestnik Jugo-Vostoka [Agrarian Bulletin of the South-East], 2009, no. 1 (1), pp. 41-44.

21. Shhur A.V., Val'ko V.P., Vinogradov D.V. Vlijanie sposobov obrabotki pochvy i vnesenija udobrenij na chislennost' i sostav mikroorganizmov [The influence of ways of soil processing and fertilization on the number and composition of microorganisms], Vestnik Kurskoj gosudarstvennoj sel'skohozjajstvennoj akademii [Bulletin of the Kursk state agricultural Academy], 2015, no. 3, pp. 41-44.

22. Jakutin M.V., Dubovik D.S. O sisteme pokazatelej monitoringa jekosistem suhih stepej [On the system of indicators for monitoring ecosystems of dry steppes], Vestnik Sibirskoj gosudarstvennoj geodezicheskoj akademii [Bulletin of the Siberian state Academy of geodesy], 2012, no. 18-2, pp. 94-99.

23. Delmont T.O., Robe P., Cecillon S., Clark I.M., Constancias P.F., Hirsch P.R., Vogel T.M. Accessing the soil metagenome for studies of microbial diversity, Applied and Environmental Microbiology, 2011, Vol. 77, iss. 4, pp. 1315-1324.

24. Drenovsky R.E., Grewell B.J., D’Antonio C.M., Funk J.L., James J.J., Molinari N. A functional trait perspective on plant invasion, Ann. Bot. , 2012, no. 110(1), pp. 141-153.

25. El-Sayed W.S., Akhkha A., El-Naggar M.Y., Elbadry M. In vitro antagonistic activity, plant growth promoting traits and phylogenetic affiliation of rhizobacteria associated with wild plants grown in arid soil, Front. Microbiol, 2014, vol. 5, pp. 651.

26. He M., Dijkstra F.A., Zhang K., Li X., Tan H., Gao Y., Li G. Leaf nitrogen and phosphorus of temperate desertplants in response to climate and soil nutrient availability, Sci. Rep., 2014, vol. 4, pp. 6932.

27. Saha P., Kumari S., Raipat B.S., Sinha M.P. Phylogenetic analysis of tolerant bacteria from Partheniumhysterophorus (1.) amended soil by bootstrap approach, International Journal of Microbiological Research, 2011, vol. 2 (2), pp. 176-183.

\section{Information about the Authors}

Nadejda Valerievna German, Candidate of Biology, Associate Professor, Associate Professor Department of Ecology and Nature Management, Volgograd State University, Prosp. Universitetskij, 100, 400062 Volgograd, Russian Federation, german@volsu.ru.

Elena Anatolyevna Ivantsova, Doctor of Agriculturall Sciences, Associate Professor, Head of Department of Ecology and Nature Management, Volgograd State University, Prosp. Universitetskij, 100, 400062 Volgograd, Russian Federation, Ivantsova@volsu.ru.

Anna Viktorovna Kholodenko, Candidate of Geography, Associate Professor, Associate Professor Department of Ecology and Nature Management, Volgograd State University, Prosp. Universitetskij, 100, 400062 Volgograd, Russian Federation, Kholodenko@volsu.ru.

\section{Информация об авторах}

Надежда Валерьевна Герман, кандидат биологических наук, доцент, доцент кафедры экологии и природопользования, Волгоградский государственный университет, просп. Университетский, 100, 400062 г. Волгоград, Российская Федерация, german@volsu.ru.

Елена Анатольевна Иванцова, доктор сельскохозяйственных наук, доцент, заведующий кафедрой экологии и природопользования, Волгоградский государственный университет, просп. Университетский, 100, 400062 г. Волгоград, Российская Федерация, Ivantsova@volsu.ru.

Анна Викторовна Холоденко, кандидат географических наук, доцент, доцент кафедры экологии и природопользования, Волгоградский государственный университет, просп. Университетский, 100, 400062 г. Волгоград, Российская Федерация, Kholodenko@volsu.ru. 